\title{
STEREOTYPIZACJA OBRAZU POLAKÓW W LITERATURZE UKRAIŃSKIEJ NA POCZACTKU XX WIEKU Z UWZGLĘDNIENIEM WSPÓŁCZESNYCH REMINISCENCJI ${ }^{1}$
}

\author{
RYSZARD KUPIDURA ${ }^{2}$ \\ (Uniwersytet im. A. Mickiewicza w Poznaniu)
}

\begin{abstract}
Słowa kluczowe: Mychajło Kociubynski, Wołodymyr Wynnyczenko, Tania Malarczuk, Irena Karpa, modernizm, postmodernizm, imagologia, postkolonializm
\end{abstract}

Key words: Mykhailo Kotsiubynsky, Volodymyr Vynnychenko, Tanya Malarchuk, Irena Karpa, modernism, postmodernism, imagology, postcolonialism

\begin{abstract}
Abstrakt: Ryszard Kupidura, STEREOTYPIZACJA OBRAZU POLAKÓW W LITERATURZE UKRAIŃSKIEJ NA POCZĄTKU XX WIEKU Z UWZGLĘDNIENIEM WSPÓŁCZESNYCH REMINISCENCJI. „PORÓWNANIA” 14, 2014, T. XIV, s. 189-205. ISSN 1733-165X. Pierwsza część artykułu stanowi refleksję na temat stanu badań nad polsko-ukraińskim dialogiem kulturowym. Autor dowodzi, że asymetryczna natura dialogu zdeterminowała tematykę podejmowanych studiów, co z kolei zaowocowało marginalizacją pewnych obszarów badawczych (np. polskich obrazów w literaturze ukraińskiej). W dalszej części szczegółowo omówione zostały postaci polskich bohaterów pojawiających się w ukraińskiej literaturze epoki modernizmu (Mychajło Kociubynski, Wołodymyr Wynnyczenko) oraz postmodernizmu (Tania Malarczuk, Irena Karpa). Zestawienie pisarzy z dwóch odległych okresów literackich pozwoliło na ukazanie modyfikacji, którym poddane zostały obrazy Polaków w literaturze ukraińskiej w ciągu ostatnich stu lat, a także na udowodnienie, że współczesne kreacje polskich etnobrazów w dalszym ciągu opierają się na stereotypach ugruntowanych w wyobraźni zbiorowej.
\end{abstract}

Abstract: Ryszard Kupidura, STEREOTYPING OF THE IMAGE OF POLES IN UKRAINIAN LITERATURE IN THE EARLY TWENTIETH CENTURY WITH A FOCUS ON CONTEMPORARY REMINISCENCES. "PORÓWNANIA" 14, 2014, Vol. XIV, p. 189-205. ISSN 1733-165X.

\footnotetext{
${ }^{1}$ Praca naukowa finansowana w ramach programu Ministra Nauki i Szkolnictwa Wyższego pod nazwą "Narodowy Program Rozwoju Humanistyki w latach 2012-2014” w ramach projektu badawczego numer: NPRH 12H 11001880.

${ }^{2}$ Correspondence Address: scholander@interia.pl
} 
The first part of the article is a reflection on the state of research of the Polish-Ukrainian cultural dialogue. The author argues that the dialogue determined the asymmetrical nature of the subject of this studies, which in turn resulted in the marginalization of certain areas of research (e.g. images of Poles in the Ukrainian literature). In the following part he discusses in detail the Polish characters appearing in Ukrainian literature of the period of modernism (Mykhailo Kotsiubynsky, Volodymyr Vynnychenko) and postmodernism (Tanya Malarchuk, Irena Karpa). The juxtaposition of writers from two distant periods allowed to show the modifications to which images of Poles in Ukrainian literature have been subjected in the past hundred years, and also to prove that contemporary creations of Polish etnoimages continue to rely on stereotypes grounded in the collective imagination.

Podejmowanie badań polskich motywów w twórczości ukraińskich autorów wszelkich epok należy do rzadkości. Tymczasem korpus tekstów poświęconych analizom obrazów Ukraińców w literaturze polskiej jest stosunkowo pokaźny. Przyczyny takiego stanu rzeczy szukać należy zapewne $\mathrm{w}$ asymetrycznej naturze polsko-ukraińskiego dialogu kulturowego, w tym literackiego, którą jeszcze w latach osiemdziesiątych zdiagnozował Hryhorij Hrabowycz. Polegała ona na tym, że polska literatura transferowała do literatury ukraińskiej przede wszystkim formy, konwencje i normy literackie, natomiast ukraińska kultura stanowiła dla polskich twórców „surowy materiał” (folklor, miejscowy koloryt, legendy, itd.), który opracowywano w manierze własnej epoki. Oprócz tego, przez wielu polskich pisarzy wspólne okresy polsko-ukraińskiej historii obrazowane były w formie mitu wyjaśniającego tragedię I Rzeczypospolitej, a część terytorium dzisiejszej Ukrainy traktowana była z silnym emocjonalnym zabarwieniem jako "ziemia ojczysta"3.

Powyższe fakty kulturowe warunkują tym samym frekwencyjność danych zagadnień $w$ podejmowanych przez badaczy studiach. Widoczne staje się to szczególnie podczas dość częstych po 1991 roku naukowych spotkań badaczy z obu stron granicy reprezentujących rodzime filologie.

Tak oto w przypadku badań nad obecnością Ukrainy i Ukraińców w literaturze polskiej podejmowane są najczęściej następujące aspekty:

1. Obrazy Ukrainy i Ukraińców w literaturze polskiej;

2. Fakty biograficzne polskich pisarzy związane z Ukrainą 4 .

${ }^{3}$ G. Grabovyč, Pol's'ko-ukrajins'ki literaturni vzaiemyny: pytannâ kul'turnoji perspektyvy. W: G. Grabovyč, Do istoriji ukrajins'koji literatury. Kijów 2003, s. 156.

${ }^{4} \mathrm{M}$. Brac'ka, "Svij” $i$ "Čužyj” kozak v poeziji ",ukrajins'koji školy" pol's'kogo romantyzmu козак y nоезï "української школи" польського романтизму. "Slovo i čas” 2005, nr 4, s. 70-78; D. Bruska, Ukraina we wczesnej poezji Juliusza Stowackiego („Dumka ukraińska”, "Piosnka dziewczyny kozackiej”, "Żmija”). W: Polska w literaturze ukraińskiej-Ukraina w literaturze polskiej. Red. S. Frycie. Piotrków Trybunalski 2003, s. 129-146; A. Chruszczyński, Ukraina w twórczości Józefa Łobodowskiego. W: Polska w literaturze ukraińskiej, op. cit., 


\title{
Odnośnie obecności Polski i Polaków w literaturze ukraińskiej badacze propo-
} nują natomiast takie ujęcia:

\author{
1. Studia ukraińskich pisarzy nad literaturą polską; \\ 2. Przekłady z literatury polskiej; \\ 3. Inspiracje literaturą polską 5 .
}

s. 215-222; P. Drobniak, „Ojczyzna bałagulska”. Ukraina w twórczości Jarosława Iwaszkiewicza. „Litteraria” 1998, t. 29, s. 151-168; E. Dutka, Ukraina w twórczości Włodzimierza Odojewskiego i Wtodzimierza Paźniewskiego. Katowice 2000, L. Hul, Motywy ukrainskie we wspomnieniach lwowskich. „Studia i Materiały” [Wyższa Szkoła Pedagogiczna w Olsztynie] 1989, nr 10, s. 93-105; S. Kozak, Ukraina w twórczości Tomasza Jeża. „Slavia Orientalis” 1969, nr 4; S. Kozak, Romantyczna Ukraina J. Stowackiego. „Warszawskie Zeszyty Ukrainoznawcze” 2000, t. X; M. Kwapiszewski, Ukraina w twórczości Zenona Fisza. „Annales UMCS" 1994/1995, vol. XII/XIII, s. 153-164; M. Kwapiszewski, Późny romantyzm i Ukraina. Z dziejów motywu i życia literackiego. Warszawa 2006; B. Łuczko-Fijałkowska, Stereotyp Ukraińca. „Dziśs" 1992, nr 8, s. 45-55; W. Mokry, Obraz Kozaczyzny w piśmiennictwie staropolskim. W: Polacy o Ukraincach, Ukraincy o Polakach. Red. S. Stegnera. Gdańsk 1993, s. 70-71; B. Mucha, Ukraińcy w „Dziennikach” Stefana Żeromskiego. W: Polska w literaturze ukrainskiej, op. cit., s. 175-184; W. Nawrocki, Strategie antystereotypizacyjne Marii Dąbrowskiej w dyskursie polsko-ukraińskim. W: Polska w literaturze ukraińskiej, op. cit., s. 185-198; L. Olander, Ukraina w twórczości Józefa Ignacego Kraszewskiego. Recepcja i poetyka. W: Polska w literaturze ukrainskiej, op. cit., s. 167-174; W. Piotrowski, Bogdan Chmielnicki i jego synowie jako bohaterowie literaccy polskiej beletrystyki z lat 1800-1850. W: Polska w literaturze ukraińskiej, op. cit., s. 155-167; J. Sawicka, Hellada scytyjska. Ukraina w poezji J. Łobodowskiego. „Więź” 1988, nr 11/12, s. 141-154; D. Sosnowska, Ambiwalencje i sprzeczności: o dziwnych Kozakach w polskiej literaturze romantycznej. „Warszawskie Zeszyty Ukrainoznawcze" 1994, t. 2, s. 165-171; D. Sosnowska, Wyprawa w głab Czortycy - Polska i Ukraina u Łobodowskiego, Odojewskiego, Mackiewicza. „Kresy” 1992, nr 9/10, s. 109-114; D. Sosnovs'ka, Stereotyp Ukrajiny ta ukrajincâ. „Ï" 1997, nr 10, s. 88-97; N. Staszenko, Ukraina w życiu i twórczości Józefa Łobodowskiego. W: Polska w literaturze ukraińskiej, op. cit., s. 199-214; E. Stryjniak-Sztankóne, Przyroda ukraińska w "Marii” Antoniego Malczewskiego. W: Polska w literaturze ukrainskiej, op. cit., s. 147-154; M. Trukhan, Negatyvnyj stereotyp ukrajincâ v pol's'kij pislâvoiennij literaturi. Mûnhen-L'viv 1992; S. Uliasz, Obrazy Ukrainy i Ukrainców w literaturze polskiej. W: S. Uliasz, O literaturze kresów i pogranicza kultur. Rzeszów 2001; S. Uliasz, Motywy ukrainskie w literaturze polskiej XX w. "Fraza" 1993, nr 3/4, s. 50-63; Z. OżógWiniarska, J. Winiarski, Antropologiczny horyzont opisów Ukrainy w poezji epickiej do okresu dojrzałego romantyzmu. W: Polska w literaturze ukraińskiej, op. cit., s. 63-128; O. Vozniuk, Imagologična viziâ Ukrajiny u tvorčosti Ie. Stempovs'kogo. "Aktual'ni problemy slov'âns'koji filologiji” 2008, t. XIX. s. 237-241. V. Osadčyj, Podillâ v pol's'kij istoriji ta kul'turi. W: Ukrajins'ko-pol'ski kul'turni vzaiemyny. V. 2. Gol. red. G.A. Skrypnyk. Kyjiv 2008, s. 210-217, A. Kalenyčenko, Karol' Šymanovs'kyj i Galyčyna. W: Ukrajins'kopol'ski kul'turni, op. cit., s. 249-274.

${ }^{5} \mathrm{O}$. Dyrybalo, Pol's'ka literatura v ukrajins'kij pys'mennyc'kij krytyci XX st.: osoblyvosti recepciji ta interpretaciji. Dys. kand. nauk. 10.01.05, Ternopil's'kyj nacional'nyj pedagogičnyj universytet imeni Volodymyra Gnatûka, Ternopil' 2008; O. Kazanowa, Vasyl' Stefanyk i pol's'ka literatura kincâ XIX - počatku XX stolittâ: aspekty hudožn'ogo dialogu. W: Kultury wschodniostowiańskie - oblicza i dialog. Rosja. Ukraina. Biatoruś. Red. A. Chudzińska-Parkosadze. Poznań 2009, s. 119-124; I. Konstantkiewycz, Polska w życiu i twórczości Maksyma Rylskiego. W: Polska w literaturze ukraińskiej, op. cit., s. 31-42; H. Korbicz, Mykota Jewszan o literaturze polskiej. W: Polska-Ukraina: partnerstwo kultur. Red. B. Bakuła, Poznań 2003, s. 45-58; G. Kočur, Zerov i Slovac'kyj, Kyjiv 1988; S. Kravčenko, Polska w życiu i twórczości ukraińskiej emigracji literackiej lat 20-30 XX wieku. W: Polska w literaturze ukrainskiej, op. cit., s. 43-48; O. Rysak, Juliusz Stowacki w interpretacji Oteny Pczitki. W: Polska w literaturze ukraińskiej, op. cit., s. 11-20; M. Khmeliuk, 
Jak wynika z powyższego schematu, o Polsce i polskich bohaterach w ukraińskich utworach literackich raczej się nie dyskutuje ${ }^{6}$. Nie oznacza to jednak, że ukraińscy twórcy milczeli o Polakach. Dla przykładu: szczególnie liczną reprezentację polskich bohaterów kryje w sobie ukraińska proza historyczna (Ołeksa Storożenko, Mychajło Starycki, Pantałejmon Kulisz, Iwan Neczuj-Łewycki i inni), inspirowana w głównej mierze poematami historycznymi Tarasa Szewczenki. Ten obszerny materiał, przepełniony nie tylko imagologicznymi obrazami, ale także historiozoficznymi wizjami mistrzów dziewiętnastowiecznej prozy ukraińskiej na temat stosunków z Rzeczpospolitą, do dziś czeka na pełne i syntetyczne opracowanie ${ }^{7}$.

$\mathrm{W}$ niniejszym artykule przeprowadzona zostanie analiza polskich postaci w twórczości dwóch ukraińskich modernistów - Mychajła Kociubynskiego i Wołodymyra Wynnyczenki - a także podjęta będzie próba odszukania analogii w obrazowaniu Polaków przez współczesne pisarki ukraińskie młodego pokolenia Irenę Karpę oraz Tanię Malarczuk. To, co będzie łączyło wszystkich wymienionych autorów, to relatywnie słabe związki z kulturą polską. Taki dobór nazwisk może zatem wydać się z pozoru paradoksalny, czy wręcz nieuprawomocniony. Przemawia za nim jednak kilka argumentów. Po pierwsze, okazjonalne, pozbawione historiozoficznych motywacji przywoływanie obrazów Polaków przez autorów nie mających stałych kontaktów z polskim narodem, może owocować eksplozją całego szeregu stereotypowych konceptów, tkwiących swymi korzeniami w kolektywnej świadomości społeczeństwa ukraińskiego. Po drugie, trzeba zauważyć, że w najnowszej literaturze ukraińskiej po 1991 roku (wyjąwszy prozę historyczną, a także eseistykę), pomimo autentycznych, bardzo bliskich stosunków z Polską wielu autorów (Jurij Andruchowycz, Ołeksandr Irwaneć, Serhij Żadan, Natalia Śniadanko i inni), temat Polaków i relacji z nimi nie był szczególnie eks-

Pol's'ka literatura v recepciji Lesi Ukrajinky. W: Lesâ Ukrajinka i sučasnist'. T. 4, ks. 1., Luc'k 2007, s. 491-498; S. Yakovenko, Ivan Bagrânyj i pol's'ka literatura. „Moloda naciâ" 1996, nr 4, s. 191-199; B. Syuta, Koncepciâ hudožn'oji cilisnosti $v$ pol's'komu postmodernizmi ta jiji recepciâ v Ukrajini, Ukrajins'ko-pol'ki kul'turni, op. cit., s. 131-145; L. Skupeyko, Pol's'ka "moderna" v interpretaciji Lesi Ukrajinky. W: Ukrajins'ko-pol'ski literaturni vzaiemyny: istoriâ, typologiâ, recepciâ. Donec'k 2012, s. 73-78.

${ }^{6}$ Tym niemniej, prowadzone są w tym zakresie badania. Jeszcze przed wojną na łamach „Biuletynu Polsko-Ukraińskiego" Paweł Zajcew analizował polskie postaci w prozie Tarasa Szewczenki. Obecnie w polskiej ukrainistyce temat ten staje się nawet dość popularny, zajmują się nim m.in. Katarzyna Glinianowicz oraz Katarzyna Jakubowska-Krawczyk. Na Ukrainie natomiast pracę doktorską na temat wizerunku Innego $\mathrm{w}$ ukraińskiej prozie historycznej przygotowuje Ołeksandr Kyryłczuk.

${ }^{7} \mathrm{Z}$ drugiej strony warto byłoby także poszerzyć w badaniach zakres polskich tekstów, które zawierają w sobie obraz ukraińskiego Innego. Obok nader dobrze już rozpoznanych motywów i postaci z prozy historycznej Henryka Sienkiewicza, czy takich autorów jak Jarosław Iwaszkiewicz, Włodzimierz Odojewski, czy Józef Łobodowski, istnieje spora reprezentacja ukraińskich obrazów w dzisiejszej popkulturze polskiej (przypomnijmy choćby obraz lwowskiego neurochirurga z S@motności w sieci Janusza Leona Wiśniewskiego, czy ufundowaną na silnym stereotypie postać ukraińskiej opiekunki do dziecka w serialu telewizyjnym Usta Usta). 
ploatowany w literaturze pięknej. Najważniejsze powieści diagnozujące postkolonialną kondycję Ukrainy dotyczyły już to jej relacji $\mathrm{z}$ rosyjskim hegemonem (Moscoviada Jurija Andrchowycza), już to z Zachodem (Badania terenowe nad ukraińskim seksem Oksany Zabużko), już to wewnętrznego napięcia, wywołanego koniecznością dokonania wyboru cywilizacyjnego (Riwne/Rowno Ołeksandra Irwancia).

Chronologicznie pierwszym z omawianych etnobrazów będzie postać Jana Skrzębrzchowskiego z opowiadania $W$ cieniu maszyny Wołodymyra Wynnyczenki z 1902 roku. Wołodymyra Wynnyczenkę, premiera Ukraińskiej Republiki Ludowej, słusznie uważa się za fenomen ukraińskiej sceny literackiej pierwszej połowy XX wieku. Autor kilkunastu powieści, ponad dwudziestu dramatów oraz około stu opowiadań, posiadający liczny dorobek publicystyczny, pamiętnikarski i epistolarny należy do plejady wybitnych polityków Europy Środkowo-Wschodniej okresu międzywojennego, jak Tomaš G. Masaryk, Józef Piłsudski czy Mychajło Hruszewski, którzy obok działalności państwowej publikowali także teksty publicystyczne, naukowe lub literackie.

W cieniu maszyny to utwór z okresu literackich debiutów Wołodymyra Wynnyczenki na samym początku XX wieku. Opowiadanie wprowadza czytelnika w tematykę nierówności społecznej i narastania rewolucyjnej atmosfery w Imperium Rosyjskim, która okaże się charakterystyczna dla całej wczesnej twórczości pisarza. Dodatkowo w tekście zostaje uchwycony zmieniający się krajobraz wsi ukraińskiej przełomu wieków:

Gdzieś ze trzy zagony od wsi Curupałki pracuje maszyna pana Skrzębrzchowskiego To jest, bracie, prawdziwe piekło. Gdy trafisz tutaj, to z początku nic nie rozumiesz: stukot, łoskot, gwałt, jakiś wrzask, jakiś świst, ktoś coś krzyczy, gdzieś się śmieją, proch, plewy, dym. Poprzez utrzymującą się dookoła mgłę widać coś wielkiego i czerwonego. Słychać, jak to coś ze złością pohukuje i hurkocze. Po chwili orientujesz się jednak $w$ tej prostej scenie. Oto stoi sobie poczciwy, nienażarty zwierz, huczy, hurkocze, a ludzie tylko napełniają mu paszczę i nie nadążają go nakarmić. Z radosnym pomrukiem łyka snop za snopem, miażdży go swoimi żelaznymi zębami i znów żałośnie krzyczy z głodu. Nie zdąży piętnaście żywych istot wygrzebać się spod niego, jak na nowo trzeba pchać mu żer do paszczy, bo już woła i kłapie swoim pustym bębnem?9.

Wynnyczenko zgodnie ze swoimi socjalistycznymi przekonaniami analizuje proces proletaryzacji wsi. Śledzi, jak nawykli do pańszczyzny chłopi zaczynają

\footnotetext{
${ }^{8}$ Ten nieudany zabieg onomastyczny demaskuje nonszalancję Wynnyczenki, typową szczególnie we wczesnym okresie twórczości. Wynnyczenko, prowadząc wówczas burzliwe życie rewolucjonisty, nie dbał specjalnie o detale stylistyczne. $W$ tym akurat przypadku nagromadzenie typowych dla języka polskiego zbitek spółgłoskowych, samogłoski nosowej $\varepsilon$ oraz typowej dla polskich nazwisk końcówki -ski utworzyło w efekcie niezrozumiały i niemiły dla ucha łamaniec językowy.

${ }^{9}$ V. Vynnyčenko, Krasa i syla. Kyjiv 1989, s. 67. Tłumaczenie własne. Dalej, jeśli nie wskazano inaczej, również.
} 
organizować się na wzór miejskich robotników. Młody ekonom, pan Gudziński, zwany przez chłopów Guzikiem, nie nadąża z rozganianiem spontanicznie gromadzących się ludzi, domagających się regularnego i uczciwego wynagrodzenia za swoją pracę. Przewodzi im młody Karpo, najbardziej krnąbrny i dążący do konfrontacji. Jednak centralną postacią utworu jest wspomniany Gudziński. Jego wszelkie działania determinuje chęć odgrodzenia się od chłopów, natomiast pochodzenie jego samego jest dość niepewne. Nie możemy z całą pewnością dowieść jego narodowości. Guzik poszukuje potwierdzenia swej przynależności do Polaków, co chce osiągnąć poprzez małżeństwo z modystką - córką polskiego przedsiębiorcy. Bratanie się z Polakami Guzik rozumie wyłącznie jako sposób na podniesienie swojego statusu społecznego i majątkowego. Nie ukrywa nawet specjalnie swej niechęci do nieurodziwej i niezbyt rozgarniętej modystki. Nienawidzi jej w takim samym stopniu, jak otaczających go parobków, ale tylko związek z nią może pozytywnie wpłynąć na jego stan posiadania:

(...) wiadomo, ile wykupnego daje mu ojciec-monopolista za nadmiernie wielkie zęby, za skośne oczy, za dwadzieścia osiem lat swojej córki, modystki. (...) wiadomo, że z wielką ochotą zamiast tego rzuciłby ją do pieca, gdyby tylko dała naprzód pieniądze. Wiadomo, że nienawidzi jej tak, jak nienawidzi teraz wszystkich obecnych koło maszyny ${ }^{10}$.

Polski dwór zostaje zaledwie wspominany przez bohaterów i nie stanowi części świata przedstawionego utworu. Czytelnik dowiaduje się jedynie, że panicz Jan Skrzębrzchowski wabi tam niekiedy chłopki, darując im w zamian za miłosną uciechę drobne upominki. Jego obraz jest wybitnie prześmiewczy:

Po pewnym czasie można było rozpoznać już ładniutką bialutką twarzyczkę pana Janka z błękitnymi, niewinnymi dużymi oczyma i świeżymi, rumianymi ustami, nad jakimi ledwie widocznie czarniały maleńkie wąsiki. Można było dostrzec na tej dziecięcej twarzy jakąś tępotę, suchość i nadzwyczajną zarozumiałośćc1.

Pojawienie się młodego pana $\mathrm{w}$ pobliżu młockarni nie zmienia specjalnie atmosfery wśród grupy pracujących ludzi. Wszyscy znają jego cel wizyty i nie próbują nawiązać żadnego kontaktu, choćby w celu poskarżenia się na niewypłacającego pensji ekonoma. Dodatkowo Wynnyczenko podkreśla dystans pomiędzy polskim paniczem a ukraińskimi chłopami poprzez fakt, że komunikacja między nimi odbywa się głównie za pośrednictwem Guzika. Panicz nie rozumie języka ukraińskiego:

- Proszę pana, dzisiaj mało ładnych. Ale ja panu pokażę, proszę pana.... - przymrużył oko na pół po przyjacielsku, na pół służalczo, z miną, jaką miewają jedynie lokaje. -

\footnotetext{
10 Ibidem, s. 68.

11 Ibidem, s. 78 .
} 
Dziewczynka... sam pan zobaczy. (...) Przeszli na drugą stronę maszyny, gdzie Guzik zaczął jeszcze bardziej demonstracyjnie pokazywać Jankowi wszystkie dziewczyny, z jadowitą radością obracał je na wszystkie boki i umyślnie smagał nahajem, jak krowy na bazarze ${ }^{12}$.

Ogarnięty chucią panicz Janek jest raczej obiektem politowania, aniżeli obrazem krwiopijcy i eksploatatora. Jest słaby i nie rozumie procesów, które zachodzą w jego posiadłości.

Całą uwage czytelnika skupia na sobie ekonom. W tle pozostaje nawet buntownik Karpo z jego tragedią i poniżeniem, po tym jak do dworu udała się jego ukochana, Chyma. Gudziński jest w istocie ilustracją opłakanego finału projektu natione Polonus, gente Ruthenus, którego domniemanym autorem był żyjący w XVII wieku Stanisław Orzechowski. Sławetni obywatele Rzeczypospolitej rusińskiego pochodzenia stali się z czasem Małopolakami13, czyli postaciami o ułomnej, skrzywionej tożsamości. Wynnyczenko kontynuuje myśl, którą tak wyraźnie zarysował w drugiej połowie XIX wieku Anatolij Swydnicki w powieści pt. Luboraccy. Za każdą próbę dokonania awansu społecznego Ukrainiec musi zapłacić wysoką cenę. Stanowi ją okaleczenie własnej tożsamości oraz odgrodzenie się od swoich. Stratyfikacja społeczna w rzeczywistości Imperium Rosyjskiego, zawierającej w sobie jednocześnie dwie aury - kolonialną i postkolonialną (w stosunku do Polaków) - była dla Ukraińców immanentnie powiązana z tożsamościowym przesunięciem. Finałem ruchów w obrębie drabiny społecznej była przeżywająca traumę postać hybrydyczna.

Bardziej wyrazisty obraz polskich mieszkańców Imperium Rosyjskiego przedstawia opowiadanie pt. Debiut Mychajła Kociubynskiego z 1909 roku, choć i w tym przypadku nie można mówić o bohaterach pierwszoplanowych. Autor - najwybitniejszy przedstawiciel impresjonizmu w literaturze ukraińskiej, jeden z jej najważniejszych modernizatorów na początku XX wieku - w liście do mecenasa Jewhena Czykałenki tak przedstawiał myśl przewodnią utworu:

Temat ciekawy. To pierwsza rola na scenie życia, pierwsza gra i razem z tym jej świadomość i jakaś siła, która ciągnie człowieka do dołu, nie daje mu zakończyć roli, przestać grać, która każe rozsiewać nasze „ja” z pełnym zawzięciem i wszelkimi sposobami, tak jak chwasty na śmietniku rozsiewają swoje nasiona ${ }^{14}$.

Nowelista w swoim głównym zamyśle przeprowadzał w Debiucie studium psychologiczne nad dialektyką konwenansów i egoizmu w pierwszych miłosnych

12 Ibidem, s. 78,80 .

13 Parafrazuję tutaj określenie „Małorosi” ukraińskiego poety i krytyka Jewhena Małaniuka, który tym mianem określał okaleczonych psychicznie i duchowo ukraińskich subalternów zamieszkujących Imperium Rosyjskie.

${ }^{14}$ M. Kociubynskyj, Tvory v semy tomah. T. VI. Kyjiv 1975, s. 112. 
poczynaniach młodego człowieka. Fakt, że jest to akurat romans z Polką, Kociubynski pomija $\mathrm{w}$ korespondencji z Czykałenką. Nie poznajemy więc motywów usytuowania akcji w polskim domu. Tymczasem charakterystyka kolejnych członków rodziny, do której przyjeżdża główny bohater (nauczyciel Wiktor) jest dość szczegółowa. Każdemu z nich autor poświęca osobny fragment. Poznajemy zatem syna powstańca styczniowego:

Pan Adam opowiada swoje przygody, kiedy po powstaniu, jeszcze jako mały chłopiec musiał uciekać z ojcem za granicę.(...) Pan Adam chodzi po domu, opowiada. Właśnie teraz błąka się po Belgii i szuka pracy. A teraz zatrudnił się już na fermie i już młóci...15.

Jest to typowy życiorys polskiego patrioty, marzącego o odzyskaniu niepodległości swojej ojczyzny, doświadczonego wieloletnią tułaczką i statusem renegata Imperium. Do czasu postać pana Adama budzi w guwernerze szacunek i sympatię. Jednak relacje między nimi szybko weryfikuje sytuacja ze złapanym ukraińskim chłopem, który kradnie cegłę z gospodarstwa Polaków:

Pan Adam mówi spokojnie:

- Łajdaku, od dawna mam cię na oku... Już dawno o tobie myślałem. Ile to razy widziałem ślady wozu koło cegielni. Teraz już wiem, czyja to sprawka. Przyznaj się, ileś nakradł? Milczysz? No, sam mi powiedz, co mam z tobą zrobić? Do więzienia wsadzić, żeby cała wieś wiedziała, żeś złodziej?

Pauza. Tępo patrzy związany, tępo świeci lichtarz, wszyscy jakby zastygli.

- Zginiesz, moje serce, w więzieniu. Przepadniesz. Skończysz jak zwykły złodziej. Ale szkoda mi ciebie. Chyba, żeby złoić cię dobrze, żebyś popamiętał. Jak się obliżesz, to odechce ci się kraść. No, mów szybko: do więzienia czy bić?

Chłop milczy, sapie ciężko i wreszcie mówi głucho:

- Bijcie.

I dalej:

Pan Adam dostał zadyszki. Obrócił się do tyłu i zobaczył mnie.

Zmieszał się.

- Z tym ludem... wie pan... lepiej...

Wylatuje ze mnie chrypliwy śmieszek.

- Cha-cha! O, pan Adam to znany apostoł oświaty...

I trzasnąłem drzwiami pod samym nosem.

Nasze stosunki z panem Adamem są oziębłe ${ }^{16}$.

Kolejną postacią jest mama Kostusia. Uwielbiająca gry karciane, trochę zdziwaczała starsza pani, która otwarcie deklaruje swoje demokratyczne poglądy.

\footnotetext{
${ }_{15}$ M. Kociubynskyj, Tvory, op. cit. T. III. Kyjiv 1974, s. 22-23.

${ }^{16}$ Ibidem, s. 32.
} 
Przestraszonej pokojówce wyrywa naczynia, po czym podnosi jej dłoń ku górze w dowód wdzięczności za pracę, jaką wykonuje. Na pustych gestach i postępowych hasłach kończy się jednak liberalizm starszej pani, która wieczorem zmęczona człapie do swojego pokoju:

Teraz już nie za prędko zobaczysz ją $\mathrm{w}$ jadalni. Na długo zaszyje się w swym kącie i tam, za pomocą pasjansa, rozwiązywać będzie kwestie socjalne ${ }^{17}$.

Staszek - najmłodszy z rodziny - jest ulubieńcem swojego wychowawcy. Wiktor nazywa go „cudownym dzieckiem” i chwali za ciekawość świata i bystrość umysłu. Staje w jego obronie, gdy chłopiec o mały włos nie wywołuje skandalu podczas wizyty stanowego.

Pewnego szarego wieczoru do jadalni pośpiesznie wnoszono światło, bo do dworu przybył stanowy. Pana Adama zbudzono i słychać było jak z jadalni dochodzi jego basowy od poobiedniego snu głos. Widziałem dwie figury, które siedziały na skraju stołu naprzeciwko siebie, kark stanowego, jego okrągłe wysokie ramiona, szeroko rozstawione nogi w błyszczących butach. (...) Raptem coś stało się. Aż podskoczyłem. Strzelają. Widzę, jak stanowy podniósł ręce i zakrył nimi głowę. Przechylił się na bok, odrzucił lewą nogę, jakby zaraz miał się przewrócić. Biegnę do jadalni i widzę okrągłe przestraszone oczy pana Adama.

Stanowy wstał.

- Co z panem? - z pośpiechem pyta pan Adam.

Stanowy zdjął $z$ głowy ręce i blady, z przestrachem ogląda palce. Jeszcze raz maca głowę, przygląda się dłoniom - nie, krwi nie ma.

Skąd strzelali?

Pan Adam milcząco wyciąga rękę w kierunku budynków gospodarczych, gdzie głębokim otworem czernieją drzwi.

Biegnę tam i na progu parzą mnie dwa węgielki Staszkowych oczu i dwie chude rączki przyciskają do piersi drewnianą pukawkę.

- Co robisz, Staszku?

- Biję Moskala ${ }^{18}$.

Starszą siostrą Staszka jest panna Aniela. To ona skupia na sobie ambiwalentne uczucia głównego bohatera i prowokuje go swoją postawą do odegrania „pierwszej roli na scenie życia". Jej oschłość i chłód korelują z ascetycznym trybem życia skupionym wokół katolickiej świątyni. Zresztą sam opis fizjonomii Anieli ukształtowany został po części przez klerykalne skojarzenia:

Być może to jedynie fantazja, ale ja widzę na jej twarzy cień księdza, a w liniach nosa i ust kościelną architekturę. W zakładkach odzieży czuję zatęchły zapach zakrystii19.

\footnotetext{
17 Ibidem, s. 25.

${ }^{18}$ Ibidem, s. 30-31.
} 
Dla zlaicyzowanego młodego ukraińskiego inteligenta Polka-katoliczka, przestrzegająca sumiennie przykazań swego obrządku, jawi się jako postać z innej epoki, trochę prymitywna, karmiąca się religijnymi zabobonami. Intelektualna przewaga Wiktora ani na chwilę nie zostaje podważona. Niedoszły romans Wiktora i Anieli jest typowym dla twórczości Kociubynskiego lustrzanym odzwierciedleniem spotkania kolonialnego. Aniela, jako przedstawicielka strony do niedawna dominującej, jest całkowicie pozbawiona prerogatyw. To, co pociąga Wiktora w pani Anieli, to jej zapóźnienie, zastanie w minionej epoce. Ich relacje wyznaczają nie rozmowy, lecz obserwacje mężczyzny:

Mój stosunek do panny Anieli przeraża mnie. Już wszyscy zauważają, że podczas obiadu nie spuszczam z niej oczu. Wiem, że w moich oczach widać rozkochanie. Chcę, aby dostrzegła to panna Aniela, a razem z tym nienawidzę jej. Odrzuca mnie jej postny wygląd, długi nos i cała płaska figura ze sterczącymi ramionami. I ten klerykalny zapach $^{20}$.

Odpychający i nęcący zarazem obraz pani Anieli popycha głównego bohatera nawet do odwiedzenia katolickiej świątyni:

W ślad za nią zacząłem chodzić w niedziele do kościoła. Tak, tak. Ja - do kościoła. Pomiędzy brzęczeniem organów a dymem $\mathrm{z}$ kadzielnic widziałem tylko wąskie pochyłe ramiona oraz końcówkę nosa, który opierał się na pobożnie złożonych dłoniach. Nienawiść do tej figury zaostrzała moją wyobraźnię²1.

Osobną uwagę Kociubynski poświęca polskiemu dworkowi. Impresjonista wkomponował go w krajobraz, odtworzony prawdopodobnie na podstawie zapamiętanych z młodości obrazków z Podola:

Dom nasz stał na wzgórzu, nad samym stawem, a za stawem zbiły się do kupy żółwie dachy miasteczka. Na lewo od niego ciągnęły się bezbrzeżne pańskie łany. Za domem rósł park i póki co, jedynie on anonsował nam jesień22.

Urządzenie pokojów i wnętrza dworku jest kolejnym potwierdzeniem polskości jego mieszkańców:

Ukradkiem chuchałem na palce i z nudów wodziłem oczyma po ścianach, po wielkim miedziorycie z Janem Sobieskim pod Wiedniem, po portrecie Kościuszki. Potem przeglądałem albumy albo zagłębiałem się w „Mohorta” Wincentego Pola z rysunkami Andriollego, z którego fantazja ilustratora wyzierała, jak bebechy z rozprutego brzucha ${ }^{23}$.

\footnotetext{
${ }^{19}$ Ibidem, s. 20.

20 Ibidem, s. 27.

21 Ibidem s. 29.

22 Ibidem, s. 20-21.

${ }^{23}$ Ibidem, s. 27.
} 
Ponowny opis polskiego "szlacheckiego gniazda" zostaje przedstawiony z mniej więcej półrocznej pespektywy:

Jeszcze dalej - sala. Już na progu widzę Kościuszkę w czerwonej czapce. Jan Sobieski nadal pod Wiedniem. Okna pełne szarego nieba ${ }^{24}$.

Pomimo nadchodzącej wiosny, nic się nie zmienia. Sobieski, który na dobre „utknął” po Wiedniem, jest aluzją, że tożsamość Polaków z ówczesnej Ukrainy zorientowana była retrospektywnie. Czasy świetności - zwycięstwa nad Turkami, insurekcja kościuszkowska - to wszystko pochłonęła przeszłość, którą polskie domy na Ukrainie hibernowały tematami rozmów, lekturami, wreszcie - wystrojem wnętrz.

To, co zwraca uwagę w obrazach Polaków u Kociubynskiego i Wynnyczenki, to przede wszystkim emocjonalna indyferentność autorów w stosunku do swoich bohaterów literackich. Trudno tutaj dopatrzeć się resentymentu, przy czym nie sposób mówić o przejawach empatii. Oczywiście w przypadku panicza Janka i jego nader prześmiewczego przedstawienia można byłoby mówić o typowym wręcz ujęciu resentymentalnym, gdyby nie fakt, że Polacy nie stanowią $\mathrm{w}$ tym utworze obiektu literackiej zemsty. Tymczasem, jak pisze Tamara Gundorowa, resentyment jest nieodłącznym elementem składowym antykolonializmu z właściwą mu chęcią wzięcia odwetu ${ }^{25}$. Jeżeli do tego wziąć pod uwagę fakt, że Wynnyczenko skupia swą uwagę przede wszystkim na fatalnej kondycji narodu ukraińskiego, a Kociubynski opowiada historię debiutu miłosnego, zrozumiemy, że kwestia polska nie zajmowała szczególnie obydwu pisarzy. Polacy nie pozostają jednak w ich twórczości wykluczeni tak, jak stało się to z Arabami w Dżumie Alberta Camusa. Są jedynie idealnymi modelami, by podług ich wzoru odmalować typowych ziemian. Tym samym uprawnionym wydaje się $\mathrm{w}$ tym przypadku stwierdzenie, że pisarze stworzyli swoje obrazy literackie $w$ oparciu o panujący w owym czasie na Lewobrzeżnej Ukrainie i Noworosji stereotyp Polaka. I w jednym, i w drugim przypadku mamy do czynienia raczej z funkcją, aniżeli pełnoprawnym, godnym pogłębionej analizy, bohaterem literackim.

Szukając odpowiedzi na pytanie o przyczynę takiego stanu rzeczy, należy wziąć pod uwagę sytuację polityczną narodu polskiego przełomu XIX/XX wieku. $\mathrm{W}$ nietzscheańskiej koncepcji resentymentu osoba lub cała zbiorowość słabszych jednostek odczuwa żal, zawiść i zazdrość w stosunku do jednostek i zbiorowości silniejszych ${ }^{26}$. Zdolność do bycia niezależnym, siła, potencja to obiekty pożądania,

\footnotetext{
${ }^{24}$ Ibidem, s. 33.

${ }^{25}$ T. Gundorova, Ressentiment $w$ perspektywie postkolonialnej. Przypadek ukraiński. „Porównania” 2007, nr 4, s. 73.

${ }^{26} \mathrm{~F}$. Nietzsche, Z genealogii moralności. Http:// nietzsche.ph-f.org/dziela/fn_gm.pdf (data dostępu: 03.09.2013).
} 
aktywizujące niechęć do ich dysponentów. Emanacją suwerenności narodu jest, oczywiście, własne państwo. Polacy, funkcjonujący już ponad stulecie w bezpaństwowej rzeczywistości oraz posiadający półwieczną przerwę $\mathrm{w}$ zbrojnych ruchach niepodległościowych, tracą $\mathrm{w}$ oczach ukraińskich pisarzy aurę atrakcyjności. Poprzez swoje zorientowanie na przeszłość i wierność religijnym rytuałom stają się w pewnym sensie coraz bardziej podobni do Żydów. Jednak o ile w stosunku do tych drugich $\mathrm{w}$ literaturze ukraińskiej zaczyna dominować $\mathrm{w}$ tym czasie atmosfera empatii 27 , o tyle w odniesieniu do Polaków wciąż zbyt żywą jest pamięć o konfliktach i zniewoleniu Kozaków przez szlachtę. Pamięć ta oraz wciąż jeszcze liczne majątki polskie $\mathrm{z}$ ukraińskimi chłopami rozsiane po Ukrainie przełomu XIX/XX wieku powodują, że literackie obrazy Polaków przepełnione są dystansem i wykreowane przez społeczny stereotyp.

Z perspektywy początku XXI wieku, czyli ponad sto lat później, sytuacja wygląda o tyle lepiej, że po upadku systemu w niemalże wszystkich aspektach relacji polsko-ukraińskich, w tym także $\mathrm{w}$ kulturalnych, nastąpił przełom, który bez przesady nazwać można „nowym otwarciem”. Jednak intensywność wymiany kulturalnej, co już sugerowano wcześniej, nie wpływa póki co na frekwencyjność polskich motywów w najnowszej literaturze ukraińskiej (znów poza nawias należy wyjąć prozę historyczną). Związane jest to $\mathrm{z}$ potrzebą uporania się $\mathrm{w}$ pierwszym rzędzie z największymi bolączkami przeszłości i teraźniejszości (Wielki Głód 1932/33, rusyfikacja, katastrofa czarnobylska, rozdarcie wewnętrzne, ubożenie społeczeństwa, emigracja itd.), do których, co dobitnie pokazują badania socjologiczne, stosunki z Polakami nie należą ${ }^{28}$. W tej sytuacji postawiona przed dekadą diagnoza Bogusława Bakuły pozostaje aktualna również dzisiaj:

Hermetyzm ukraińskiej kultury nie wynika z jej niechęci do kontaktów zewnętrznych, lecz z faktu, iż zmaga się ona $\mathrm{z}$ wewnętrznymi kłopotami o charakterze postkolonialnym, z kompleksem „ojczyźnianym” i swoją zadawnioną niechęcią wobec „kosmopolityzmu", to znaczy absorbowania innych wartości, nienarodowych, w sytuacji nieustającego zagrożenia, trwającego dziesiątki, jeśli nie setki lat ${ }^{29}$.

Polskie motywy są zatem, podobnie jak przed stu laty, najczęściej okazjonalne i zakorzenione w społecznym stereotypie.

Relatywnie dużym zainteresowaniem kilka lat temu cieszyła się w Polsce książka pt. Freud by ptakał Ireny Karpy. Autorka powieści uchodzi na Ukrainie za prowokatorkę i skandalistę. Będąc wokalistką i autorką tekstów zespołu rockowe-

\footnotetext{
${ }^{27}$ Swój wkład wnieśli również omawiani autorzy. Zob. G. Grabovyč, Ievrejs'ka tema v ukrajins'kij literaturi XIX ta počatku XX storiččâ. W: G. Grabovyč, op. cit., s. 218-238.

${ }^{28}$ Zob. J. Konieczna, Polska-Ukraina wzajemny wizerunek. Raport z badań. http://www.isp.org. pl/files/5655578580364032001225889489.pdf (data dostępu: 03.09.2013).

${ }_{29}$ B. Bakuła, Kryzys i przełom w perspektywie polsko-ukraińskich zwiazków kulturowych w XX wieku. W: Polska-Ukraina: partnerstwo kultur, op. cit., s. 14.
} 
go Fucktychno sami, jako jedna z pierwszych zaczęła używać w swych tekstach wulgaryzmów. Chętnie pozuje do zdjęć dla ukraińskich edycji popularnych czasopism erotycznych, co w społeczeństwie wciąż jeszcze obarczonym sowiecką pruderyjnością wywołuje spore oburzenie. Jako pisarka Irena Karpa debiutowała w roku 2000. Obecnie posiada w swym dorobku kilkanaście tytułów.

Freud by ptakat traktuje o trudnych relacjach ludzi z odrębnych obszarów kulturowych, o problemach komunikacji interpersonalnej i o tym, że nawet $\mathrm{w}$ czasach galopującej globalizacji nasze wzajemne upodabnianie się do siebie ma swoje wyraźne granice. Złożone relacje w czworokącie miłosnym, w skład którego wchodzą Ukrainka Marla Friksen i troje jej kochanków: Fin Hjalmar, Rosjanin Iliia oraz Polak Andrzej, dzięki nasyceniu poszczególnych etnoobrazów kontekstem kulturowym, można odczytać na poziomie metaforycznym jako dylemat cywilizacyjnego wyboru Ukrainy.

Hjlamar pochodzi z fińskiej rodziny i jest wzorcowym przedstawicielem młodego intelektualisty z Europy Zachodniej. Jego światopogląd jest mieszanką typowej dla świata akademickiego Zachodu lewicowości z alterglobalizmem i ekologią, zbudowany na lekturze poświęconej problematyce gender i łamaniu praw człowieka, przeplatanej dodatkowo fragmentami z Mahatmy Gandhiego. Granty pozyskane w rodzimej „kulturze możliwości” pozwalają na to, by Hjalmar w czasie swojej podróży po Azji poobserwował, pokwalifikował i pooceniał mieszkańców „kultury beznadziei”. Marla intuicyjnie wyczuwa zakłamanie takiej postawy i nie tyle buntuje się przeciwko niej, ile jawnie ją wykpiwa. Drwi z idealistycznych chęci Hjalmara, by poprawić świat, a do tego - jako osoba pochodząca z kraju doświadczonego przez komunizm - uważa jego przychylny stosunek do nepalskich maoistów za szczyt naiwności. Jej brak wiary w sensowność poczynań Hjalmara zostaje wyrażony wprost: [Marla] „niezupełnie wierzyła w wartość jego (Hjalmara) działań, gdy pisał książki o tym, jak obsrała się ONZ w krajach Azji i Afryki, za które w dodatku płaciła sama ONZ"30.

Rosja, reprezentowana przez beneficjentów gospodarki opartej na rabunkowej eksploatacji i wyprzedaży surowców naturalnych to z kolei „kultura nadmożliwości". W Freud by płakat reprezentuje ją petersburżanin Illia, który w kieszeni zawsze ma tysiąc lub dwa, zaś na koncie milion lub dwa. Kijów stanowi dla niego wciąż jeszcze prowincję wielkiego imperium, atrakcyjną dla Rosjanina jedynie jako miejsce taniej rozrywki. Ekskluzywne kasyno na Chreszczatyku, niedostępne dla większości mieszkańców miasta, pozwala Illi zaspokoić chwilowy kaprys. Podobnie jak Marla, uczestniczy w show biznesie, jednak jego działań nie motywuje chęć zrobienia artystycznej kariery, lecz oportunistyczna dbałość o zaspokojenie niskich zachcianek jeszcze bogatszych od niego biznesmenów. Sposobem na zarobienie

${ }^{30}$ I. Karpa, Freud by ptakat. (Mar-o-Mar). Ponieść (bo dlaczego zawsze powieść). Przeł. M. Petryk. Wołowiec 2006, s. 162. 
pokaźnej sumy pieniędzy jest organizowanie prywatnych koncertów Britney Spears i nagrywanie kiczowatych klipów z prymitywną fabułą. Illia jest zatem przeciwieństwem Hjalmara. Swej pozycji nie buduje on na potencjale intelektualnym, lecz materialnym. Co ciekawe, Ukrainkę Marlę pociąga zarówno jedno, jak i drugie.

Na tym tle etnoobraz polskiego kochanka wydaje się uproszczony i mizerny. Poeta Andrzej z Krakowa (a jakże!) opuszcza Marlę, by spotykać się w Polsce ze swoimi katolickimi (a jakże!) wielbicielkami.

A potem Andrzej z Polski (pojechał tam chyba na swój własny wieczór poezji) pisał jej listy o tym, jak chcą się z nim dymać dwudziestoletnie polskie katoliczki, trzydziestoletnie polskie krytyczki i czterdziestoletnie wydawczynie.

- Hurra!!! - pisała Marla - Weź, p...1 je wszystkie jak leci!!! Tylko bez fanatyzmu, w prezerwatywie. Nie chcę potem jeździć do ciebie w gości aż do Krakowa, żeby chwalić twoje tłustozade dzieci i żonę katoliczkę...

Fragmenty powieści, w których Marla romansuje z Hjalmarem i Ilią, przesycone są intertekstualnością, odsyłającą czytelnika do klasyki literatury rosyjskiej (Lew Tołstoj, Wladmir Nabokow) oraz ikon popkultury zarówno Zachodu, jak i Wschodu (Tom Waits, Tricky, Zemfira). Epizody z Andrzejem są kontekstowo jałowe, a polski entoobraz marginalny i nieistotny w strukturze całego tekstu. Czytelnik ulega wrażeniu, że autorce zabrakło zarówno pomysłu, jak i pretekstu do rozbudowania literackiego obrazu kochanka z Polski.

Urodzona w 1983 roku Tania Malarczuk, w przeciwieństwie do Karpy, nie została beneficjentką boomu na ukraińską literaturę, który zapanował na polskim rynku wydawniczym w pierwszej dekadzie XXI wieku. W tym okresie zaczęli się publikować po polsku m.in. Taras Prochaśko, Serhij Żadan, Lubko Deresz, Natalka Śniadanko, Sofia Andruchowycz. Proza Malarczuk polskiej publiczności została zaprezentowana jedynie fragmentarycznie w antologii autorów z Europy Środkowo-Wschodniej oraz na literackim portalu internetowym „Radar"31. Szkoda, bo to ważna dla Ukrainy autorka, z dziennikarskim zacięciem pisząca o kondycji współczesnego ukraińskiego społeczeństwa, a stylem pisarskim przypominająca niekiedy uwielbianego w Polsce Tarasa Prochaśkę.

Na pierwsze polskie ślady $\mathrm{w}$ twórczości Malarczuk natrafiamy $\mathrm{w}$ zbiorze trzech opowiadań Jak zostałam świętą ${ }^{32}$. W jednym z tekstów, demaskującym ksenofobię ukraińskiej prowincji, pojawia się postać starego Polaka Witolda. Jest on członkiem lokalnej wspólnoty i jednym z prowodyrów napiętnowania obcych.

${ }^{31}$ Ludzie, miasta. Literatura Biatorusi, Niemiec, Polski i Ukrainy. Antologia tekstów. Red. P. Marecki, R. Serednicka, I. Stokfiszewski. Kraków 2008; http://e-radar.pl/pl,autorzy,1830.html (data dostępu: 03.09.2013)

${ }^{32}$ T. Malyarchuk, Âk â stala svâtoû. Kharkiv 2006. 
Wyróżnia go jednak - podobnie jak w przypadku bohaterów Kociubynskiego stałe zorientowanie $\mathrm{w}$ stronę przeszłości. Witold $\mathrm{z}$ uporem powraca $\mathrm{w}$ rozmowach do czasów, kiedy to „żył jeszcze Gombrowicz”, a miasteczko, w którym rozgrywa się akcja, "wchodziło w skład jednego organizmu państwowego wraz z Wenecją i Wiedniem" 33 . Niezgodność chronologiczna wskazuje na nostalgiczną tęsknotę za mitycznymi "złotymi czasami", na którą cierpi wykreowany przez Malarczuk przedstawiciel polskiej diaspory.

W całkowicie odmiennym kontekście pojawiają się Polacy w Biografii przypadkowego cudu - najnowszej pozycji w dorobku Malarczuk:

Tymczasem do wsi, gdzie mieszkała babcia, przyjechali polscy księża odnawiać kościól.

(...) to był jakiś szczególny zabytek ich polskiej kultury. W dzień św. Antoniego - to też jakieś ich wielkie święto - miało odbyć się uroczyste otwarcie kościoła i pierwsza msza. Z Polski przyjechało dziesięć autobusów pielgrzymów i zwyczajnych turystów. Wielu $\mathrm{z}$ nich miało swe rodziny $\mathrm{w}$ tej wsi, błąkali się przez to na polskim cmentarzu odnajdowali znajome nazwiska i płakali jak dzieci.

Miejscowi również ubrali się uroczysto i zebrali się obok kościoła jakby wszyscy mieli naraz rzucić się na kolana i przysięgać wierność papieżowi. W rzeczywistości wszyscy czekali na prezenty.

Ktoś puścił plotkę, że Polacy przywieźli ze sobą napchane worki i podczas ceremonii będą rozdawać miejscowym drogą polską odzież i zamorskie delikatesy. Za darmo, z czystej dobroci.

Ludzie zebrali się i niecierpliwie czekali. Dzieci tłoczyły się tuż obok, gotowe na pierwszą komendę rzucić się do ataku.

Ceremonia biegła powoli. Ludzie przestępowali z nogi na nogę. Polski kapłan, przystojny młodzieniec, łamanym ukraińskim wygłosił wzruszającą przemowę o czasie i pamięci. Dziękował miejscowym za opiekę nad polskim kościołem i niektórzy mężczyźni w tłumie ze wstydem opuścili oczy.

W końcu z autobusów zaczęli wynosić długo oczekiwane worki z darami. Ludziom zaiskrzyły się oczy. Wiedzieli, że to dla nich i nie czekając na pozwolenie, ani na dokończenie uroczystych wystąpień, rzucili się na worki jak kojoty na martwą antylopę. Polacy, którzy nieśli worki, początkowo próbowali się bronić, ale szybko zorientowali się, że ich zadepczą i uciekli.

Worki zaczęły pruć się w szwach i na zewnątrz wysypały się tony cukierków ${ }^{34}$.

Zaskakujące jest to, że w tej scenie Malarczuk nie buduje postkolonialnego napięcia. Biografia... to powieść o pokoleniu dzisiejszych trzydziestolatków z Ukrainy Zachodniej. Historia życia głównej bohaterki Leny ukazana jest na tle rzeczywistości pierwszych lat niepodległej Ukrainy - od dziecinnie naiwnej euforii po upadku ZSRR, poprzez biedę i chaos lat dziewięćdziesiątych, skończywszy na doj-

\footnotetext{
33 Ibidem, s. 98.

${ }^{34}$ T. Malyarchuk, Biografiâ vypadkovogo čuda. Kharkiv 2012, s. 44-45.
} 
rzewaniu w warunkach skrajnie skorumpowanego, acz ustabilizowanego systemu społecznego początku XXI wieku. Jako mieszkanka zachodniego regionu Ukrainy, Lena od dzieciństwa miała wszczepioną niechęć do wszystkiego, co rosyjskie. Wrogość wobec Rosji była tak samo naturalna i spontaniczna, jak miłość do Ukrainy. Malarczuk pokazuje dramat dziecka, które, nauczone nienawiści do okupanta, nawiązuje emocjonalną więź z rosyjskojęzyczną wychowawczynią z przedszkola.

W historii z Polakami antykolonialny resentyment jest nieaktywny. Widok Polaków restaurujących katolicką świątynię nie wywołuje wśród obserwujących to Ukraińców lęku przed restytucją dawnych porządków. To musi dziwić, szczególnie, jeśli ma się w pamięci analogiczne wizyty Niemców na terenach Ziem Odzyskanych. Przypomnijmy chociażby scenę z Domu dziennego, domu nocnego Olgi Tokarczuk:

Niemcy wysypywali się z autokarów, które nieśmiało, żeby nie rzucać się w oczy, przystawały na poboczach dróg. Szli małymi grupkami albo parami, najczęściej parami. On i ona, jakby szukali miejsca na miłość. Robili zdjęcia pustym przestrzeniom, co dziwiło wielu ludzi. Dlaczego nie robią zdjęć nowemu przystankowi, nowemu dachowi kościoła, tylko pustym przestrzeniom zarośniętym trawą. Wiele razy podejmowaliśmy ich herbatą i ciastkami. Nie rozsiadali się na krzesłach, nie prosili o więcej. Kończyli tę herbatę i szli. Było nam niezręcznie, gdy chcieli wcisnąć nam w dłoń kilka marek. Baliśmy się, że wyglądamy jak barbarzyńcy w tych naszych wiecznych remontach, z tynkiem osypującym się na ziemię, z przegniłym stopniem schodów. Gdziekolwiek szli, zawsze w końcu znajdowali się pod sklepem, gdzie czekały na nich małe dzieci i wyciągały ręce po cukierka. To niektórych oburzało i zawsze robiło się trochę nieprzyjemnie. W ciągu tych kilku minut, gdy Niemcy rozdawali cukierki koło sklepu, wibrowało nad naszymi głowami coś bardzo patriotycznego, robiło się biało-czerwono, jakby w powietrze uniosła się zetlała do konsystencji gazy narodowa flaga i nawet czuliśmy się wtedy, na przekór tym cukierkom, Polakami ${ }^{35}$.

Te dwie bliźniaczo podobne do siebie sceny różnią jedynie tym, że u Polaków aktywizuje się poczucie dumy narodowej połączone $\mathrm{z}$ - jak się okazuje $\mathrm{w}$ dalszym fragmencie tekstu - obawą przed utratą majątku. Mylne byłoby jednak odczytanie per analogiam sceny z Biografii... Malarczuk jako obrazu Ukraińców łatwo wchodzących w rolę pogodzonych ze swoim kolonialnym statusem subalternów. Polacy $\mathrm{w}$ literackich wizjach ukraińskich pisarzy są tak bardzo zapatrzeni i osadzeni w przeszłości, że trudno wyobrazić sobie, by mieli jakiekolwiek zaborcze plany na przyszłość.

Podsumowując ten przegląd polskich etnoobrazów w wybranych utworach literatury ukraińskiej, można łatwo ulec pokusie stwierdzenia, że oto, pomimo wielowiekowego sąsiedztwa i nieodzownego przełomu w relacjach społeczno-politycznym po 1991 roku, obydwa narody wciąż pozostają w stosunku do siebie

${ }^{35}$ O. Tokarczuk, Dom dzienny, dom nocny. Kraków 2005, s. 123-124. 
„bliskimi nieznajomymi”. To nieprawda. Istnieje przecież szereg innych dowodów, że dialog polsko-ukraiński postępuje z każdym rokiem i z każdym rokiem uczymy się coraz lepiej odczytywać własne kody kulturowe. Być może literatura zaabsorbuje te fakty z pewnej perspektywy czasowej. Na pewno ważnym krokiem w tę stronę jest tegoroczna książka Przyjdzie Mordor i nas zje Ziemowita Szeczereka, która gatunkowo plasuje się pomiędzy powieścią drogi a reportażem ${ }^{36}$. Szczerek bezlitośnie obnaża polskie motywacje wypraw na Wschód po 1991 roku (naiwny sentymentalizm, chęć odreagowania kompleksów postkolonialnych, w końcu młodzieńczo-studenckie pragnienia przeżycia przygody $\mathrm{w}$ postsowieckim hardcorze), z drugiej strony pisze wprost o tym, co go drażni u Ukraińców. Zbyt mało czasu upłynęło od publikacji, byśmy mogli stwierdzić, w jaki sposób książka ta została odebrana na Ukrainie, jednak w pierwszych recenzjach poeta Andrij Bondar chwalił Szczereka za porzucenie nostalgicznego stylu oraz powstrzymywanie się od nieszczerych komplementów. Czas pokaże, czy ukraińska odpowiedź wyjdzie ostatecznie z szeregu licznie odwiedzającej Polskę ukraińskiej elity intelektualnej i artystycznej, czy też być może z zastępów gastarbeiterów ze Wschodu, którzy - o czym może się przekonać Paweł Łoziński, twórca dokumentu Pani z Ukrainy - potrafią równie bacznie obserwować swoich polskich pracodawców ${ }^{37}$.

36 Z. Szczerek, Przyjdzie Mordor i nas zje, czyli tajna historia Stowian, Kraków 2013.

$37 \mathrm{~W}$ tym obrazie reżyser przeprowadził wywiad z Łesią Hładkyj, która pracuje u niego w mieszkaniu w charakterze pomocy domowej. Schowany za kamerą Łoziński przepytuje Ukrainkę o szczegóły życia rodzinnego i problemy w relacjach z mężczyznami. Kobieta zwierza się ze swych intymnych przeżyć, nie porzucając przy tym swych obowiązków sprzątaczki, kucharki i garderobianej. Zob. tekst D. Dabert, Czy możliwe jest dzisiaj w Polsce kino kolonialne? Przypadek Pani z Ukrainy Pawła Łozińskiego. „Porównania” 2013, nr 13, s. 157-166. 